\title{
İşitme kayıplı ve normal işiten okul öncesi dönem çocukların erken matematiksel akıl yürütme becerilerinin karşılaştırılması*
}

\author{
The comparison of early mathematical reasoning skills in preschool \\ children with normal hearing and hearing loss
}

\author{
Pelin Piştav Akmeşe ${ }^{1}$, Gizem Kol ${ }^{2}$, Gülce Kirazlı ${ }^{3}$, Aslı Suner ${ }^{4}$, Fatih Öğüt ${ }^{5}$
}

\begin{abstract}
Makale Geçmisi
Geliş : 29 Temmuz 2019

Düzeltme : 23 Aralık 2019

Kabul : 20 Mart 2020
\end{abstract}

\section{Makale Türü}

Arastirma Makalesi
Öz: Bu araştırmada, işitme kaybına bağlı olarak koklear implant kullanan ve normal işiten okul öncesi dönem çocukların matematiksel akıl yürütme becerilerinin karşılaştırılması amaçlanmıştır. Araştırmaya, okul öncesi dönemde (60-72 ay) anasınıfına ve özel eğitim merkezine devam eden 22 koklear implantlı çocuk ve bu çocuklarla yaş ve cinsiyete göre eşleştirilmiş anasınıfi öğrencisi 22 normal işiten çocuk dahil edilmiștir. Araştırmaya katılan çocuklara, Ergül tarafindan 2014 yılında geliștirilen, "Erken Matematiksel Akıl Yürütme Becerileri Değerlendirme Aracı” uygulanmıştır. Veriler, Mann-Whitney U, Kruskal-Wallis H, Spearman's rho testleri ile analiz edilmiştir. Araştırma sonucunda; koklear implantlı çocukların tüm alanlarda, normal işiten yaşıtlarının gerisinde kaldığı belirlenmiştir. Ayrıca koklear implant kullanım süresi ve özel eğitim süresi ile değerlendirme aracındaki puanlar arasında pozitif korelasyon bulunmuştur.

Anahtar Kelimeler: İşitme kaybı; Koklear implant; Matematiksel akıl yürütme.

Abstract: This study aims to compare the mathematical reasoning skills of the preschool children who use cochlear implant due to hearing loss with the children with normal hearing. Twenty-two children with cochlear implant who continue kindergarden (60-72 months) and special education centers and twenty-two kindergarden children with normal hearing who match with these children in terms of age and gender participated in the study. The "Early Mathematical Reasoning Skills Assessment Tool", which was developed by Ergül in 2014, was applied to the children participating in the study. The findings of the study were analyzed by Mann-Whitney U, Kruskal-Wallis H, Spearman's rho tests. As a result of the study; children with cochlear implant were found to be behind the normal hearing peers in all areas. In addition a positive correlation was found between the duration of cochlear implant use and the duration of special training and the scores in the assessment tool.

Keywords: Hearing loss; Cochlear implant; Mathematical reasoning.

DOI: $10.24130 /$ eccd-jecs. 1967202041177

\footnotetext{
* Bu çalışma Ege Üniversitesi Sağlık Bilimleri Enstitüsü Kulak Burun Boğaz Anabilim Dalı Odyoloji, Ses ve Konuşma Bozuklukları Programında Gizem Kol'un Doç Dr Pelin Piştav Akmeşe ve Prof Dr Fatih Öğüt'ün danışmanlığında "Koklear İmplantlı Okul Öncesi Dönem Çocuklarda Erken Matematiksel Akıl Yürütme Becerilerinin Değerlendirilmesi” başlıklı yüksek lisans tezinden üretilmiștir.

Bu çalışmanın bir bölümü 6-9 Kasım 2019 tarihleri arasında İzmir'de gerçekleştirilen 29. Ulusal Özel Eğitim Kongresi'nde Koklear İmplantlı Okul Öncesi Dönem Çocuklarda Erken Matematiksel Akıl Yürütme Becerilerinin Değerlendirilmesi başlı̆̆ ile sözlü bildiri olarak sunulmuştur. Başlıca Yazar: Doç. Dr. Pelin PIŞTAV AKMEŞE, Ege Üniversite, Eğitim Fakülte, Özel Eğitim Bölümü, pelin.pistav.akmese@ege.edu.tr

${ }^{1}$ Doç. Dr. Pelin PIŞTAV AKMEŞE, Ege Üniversite, Eğitim Fakülte, Özel Eğitim Bölümü, pelin.pistav.akmese@ege.edu.tr, ORCID:0000-00018269-3899

${ }^{2}$ Gizem KOL, Ege Ses Terapi Özel eğitim ve Rahabilitasyon Merkezi, gizem.kol@hotmail.com, ORCID: 0000-0002-5277-605X

${ }^{3}$ Gülce KİRAZLI, Ege Üniversitesi, Atatürk Sağlık Hizmetleri Meslek Yüksekokulu/Tıp Fakültesi Kulak Burun Boğaz Anabilim Dalı Odyoloji, Ses ve Konuşma Bozuklukları Bölümü, gulce.kirazli@ege.edu.tr, ORCID: 0000-0001-7108-9987

${ }^{4}$ Aslı SUNER, Ege Üniversitesi, Tıp Fakültesi, Biyoistatistik ve Tibbi Bilişim Anabilim Dalı, asli.suner@ege.edu.tr, ORCID: 0000-0002-6872-9901

${ }^{5}$ Fatih ÖĞÜT Ege Üniversitesi, Tip Fakültesi Kulak Burun Boğaz Anabilim Dalı Odyoloji, Ses ve Konuşma Bozuklukları Bölümü ,

mehmet.fatih.ogut@ege.edu.tr, ORCID:0000-0003-2116-9940
} 


\section{SUMMARY}

\section{Introduction}

The reasoning skills are the main way of thinking and expressing for people. Reasoning skills express how the information obtained while adjusting to the ever-changing and developing world is organized in the human mind. Reasoning forms the basis of mathematical inference and number system. For this reason, conceptual understanding, mathematical reasoning and communication skills should be given priority in math class (Arnas, Gül ve Sığırtmaç, 2003; Titus, 1995). The deficiencies in problem solving skills are related to the lack of knowledge in mathematical reasoning skills. Researches show that the difference between the students with normal hearing and the hearing-impaired students is due to the lack of knowledge resulted from lack of experience (Maltzan, 2005).

Children with hearing loss who had auditory deprivation during the learning and developmental processes are inadequate in terms of associating, interpreting, making decisions, reaching conclusions and evaluating cause-effect relationships compared to their peers. Lack of auditory stimuli negatively affects the language development of children (Şipal, 2008; Yücel, 2012).

The problems that these children have in language and speech cause difficulties in cognitive, social and academic fields. Learning mathematics is one of the major academic challenges for children with hearing loss. The development of mathematical reasoning skills is of great importance for the development of unique thinking and clear and correct expression skills (Tanrıdiler, 2013). Since math teaching is often in the form of complex verbal explanations, children who have difficulty in a complex language due to hearing loss have also difficulty in learning mathematical concepts (Nunes ve Moreno, 2002).

Although it is known that mathematical problem solving is a major difficulty for many students with hearing loss, it should not be overlooked that individual differences have an effect on the understanding of mathematical concepts. Studies have found that mathematical reasoning in children with hearing loss is different from children with normal hearing (Wood, Wood, and Howarth, 1983). It is known that these children perform poor performance in mathematical reasoning skills compared to their normal hearing peers.

When the national and international literature is examined, no study has been found about the mathematical reasoning skills of children with cochlear implants. In this respect, this study aimed to compare mathematical reasoning skills of preschool children with cochlear implants (60-72 months) and normal hearing children and to determine the effect of cochlear implant use on mathematical reasoning skills. 


\section{Method}

The study was carried out in Ege University Medical Faculty Hospital Otorhinolaryngology (ENT) Department. Twenty-two children with cochlear implant who continue kindergarden (60-72 months) and special education centers and twenty-two kindergarden children with normal hearing who match with these children in terms of age and gender participated in the study. The "Early Mathematical Reasoning Skills Assessment Tool (MAYBDA), which was developed by Ergül in 2014, was applied to the children participating in the study. There are 40 questions in the evaluation tool consisting of various pictures and materials. The implementation of the assessment tool was carried out in an individual interview with the children. The findings of the study were analyzed by Mann-Whitney U, Kruskal-Wallis H, spearman's rho tests.

\section{Results}

As a result of the study; according to the scores obtained from MAYBDA, children with cohlear implant were found to be behind the normal hearing peers in all areas. In addition, the effect of cochlear implant age, age of hearing loss diagnosis, age of commencement of special education, duration of cochlear implantation, duration of special education and the educational level of the parents were evaluated. Accordingly, it was determined that the scores did not differ according to the age of the diagnosis of hearing loss, and that, according to the age of the cochlear implant and the age of the special education, there was a significant difference in the "area questions" in MAYBDA. Again, according to the level of father education, there was no significant difference in the scores of the children with cochlear implant and normal hearing. According to the mother education level, children whose mothers have high school or higher education level were found higher level than the children whose mothers have primary education level and the difference was significant in the cochlear implant group. No difference was found between mothers in normal hearing groups according to their education level. A positive correlation was found between the duration of cochlear implant use and the duration of special education and the scores in the assessment tool.

\section{Conclusion and Discussion}

In this study, it was seen that preschool children using CI had a certain level of reasoning ability but when compared with their hearing peers, children with CI fell behind normal hearing peers. It was observed that children with CI pointed out by their hands when answering the questions in MAYBDA, and subsequently they either did not answer the question "why? or answered in non-comparative way and shortly. As a result, children with CI need more support in order to perform better in mathematical reasoning skills which are the basis of mathematics. 


\section{GİRIŞ}

İnsanın düşünürken, ifade ederken kullandığ1 yollardan en temel olanı, sahip olduğu akıl (mantık) yürütme becerileridir. Akıl yürütme becerileri, sürekli değişen ve gelişen dünyaya ayak uydururken elde edilen bilgilerin, insan zihninde nasıl düzenlendiğini ifade eder. Doğrudan ya da dolaylı olarak karşılaşılan durumlar sonucu elde edilen bilgiler, akıl yürütme becerileri ile analiz edilerek bir sonuç veya karara ulaşılmasını mümkün kılar (Ergül, 2014).

Akıl yürütme, matematikte sonuç çıkarma ve sayı sisteminin temelini oluşturmaktadır. Bu sebeple, matematik dersinde kavramsal anlama, matematiksel akıl yürütme yeteneği ve iletissim kurma becerisi öncelikli olmalıdır (Arnas, Gül ve Sığırtmaç, 2003; Titus, 1995). Problem çözme becerilerindeki eksiklikler, matematiksel akıl yürütme becerilerindeki bilginin eksikliği ile ilişkilidir. Yapılan araştırmalar da göstermektedir ki, normal işiten (Nİ) ve işitme kayıplı öğrenciler arasında ortaya konan farklılıklar deneyimsel eksikliğin getirdiği bilgi eksikliğinden kaynaklanmaktadır (Fathima ve Rao, 2008; Keenan, 2006; Maltzan, 2005).

Öğrenme ve gelişim süreçleri boyunca işitsel yoksunluk yaşayan işitme kayıplı çocuklar, ilişkilendirme, yorumlama, karar verme, sonuca ulaşma, neden- sonuç ilişkilerini değerlendirmede Nİ yaşıtlarına göre yetersiz kalmaktadırlar. İşitsel uyaran eksikliği, çocukların dil gelişimlerini de bu doğrultuda olumsuz etkilemektedir (Şipal, 2008; Yücel, 2012). Bu çocukların dil ve konuşmada yaşadıkları problemler de, bilişsel, sosyal, akademik alanda güçlükleri beraberinde getirmektedir. Matematik öğrenimi, işitme kayıplı çocukların yaşadığı akademik zorlukların başında gelmektedir.

İleri ve/veya çok ileri derece işitme kaybı genellikle kokleadaki tüy hücrelerinin zarar görmesi ya da hiç oluşmaması ile ortaya çıkmaktadır (Wilson, 2000). Koklear implant (KI), tüy hücrelerinin fonksiyonunu yerine getirmek amacıyla, ameliyatla kokleaya yerleştirilen ve işitme sinirinin elektriksel yolla uyarılmasını sağlayan elektronik bir cihazdır. Bu cihazlar çift taraflı (bilateral), ileri ve/veya çok ileri derecede sensörinöral işitme kaybı olan ve işitme cihazlarından çok az yarar gören veya hiç yararlanamayan çocuklara uygulanmaktadır (Zwolan, 2015). Koklear implant, kokleadaki hasarlı kısmı atlayarak, işitsel sinirden işitme korteksine direkt elektrik uyarımı sağlar (Wilson ve Dorman, 2008). İmplantın etkili bir şekilde çalışması için işitme sinirinin fonksiyon gösteriyor olması önemlidir (Hughes ve Galvin, 2013).

Matematiksel akıl yürütme, matematik becerilerinin temelini oluşturur. Matematiksel akıl yürütmenin daha net anlaşılabilmesi için, "akıl yürütme", "mantık", "muhakeme” gibi kavramların daha detaylıca incelenmesi gerekmektedir. İzleyen bölümde bu kavramlara yer verilecektir. 
Mantık: Mantık, belirli kurallar ve ilkeler çerçevesinde yürütülen veya değerlendirilen bir çeşit akıl yürütmedir. Grünberg (2013), mantığ1 doğru düşünmenin (akı1 yürütmenin) kurallarını ortaya koymayı amaçlayan biçimsel (formel) bir disiplin, felsefenin temel bir altalanı ve yöntemi olarak tanımlamıştır. Felsefe, kimya, matematik ya da diğer alanların tümünün temelinde mantık yatar (Grünberg, 2013, Köknel, 2003).

Mantıksal düşünme, kişinin, herhangi bir problemle ilgili olarak fikirlerini ardışı biçimde düzene koymasını gerektirir. Bu şekilde birey, derin düşünce yöntemiyle, kendi kararlarıyla sonuca ulaşabilir (Sert Ç1bık ve Emrahoğlu, 2008).

Akıl Yürütme: En genel haliyle akıl yürütme, kişinin belirli deneyimler sonucu kazandığı bilgileri kendi mantık çerçevesinde kurgulayarak, bir karara ya da sonuca ulaşması sürecidir. Akıl yürütme ve mantık birbirinden bağımsız olarak düşünülemez (Ergül, 2014). Akıl yürütme becerisi geliştirilebilen bir özelliktir ve bireyin içinde yaşadığı ortamla, kültürle birebir ilişki içerisindedir. Kültürel çeşitliliğin olduğu ortamlarda akıl yürütme becerileri zenginleşip kalıcı hale gelir (Ergül, 2014; Keenan, 2006; Umay, 2003).

İki-yedi yaşlarını kapsayan işlem öncesi dönemde çocuk, hızlı bir dil gelişimi ve iletişim sürecini yaşar. Sebep-sonuç ilişkilerini keşfetmeye, akıl yürütmeye, zaman, mekân, sayılar gibi kavramlarla ilgili çeşitli ilişkileri öğrenmeye ve dünyayı daha iyi anlamaya başlar (Erdoğan ve Baran, 2003). Okul öncesi dönem çocuklarının akıl yürütme becerilerinin, çocukların düşünme ve mantık özelliklerine uygun olarak en açık şekilde görülebileceği alanların en başında matematik gelmektedir (Umay, 2003).

Meyer (2003), akıl yürütmenin matematik başarısı için gerekli olan yüksek dereceli bir bilişsel yetenek olduğunu ifade etmiştir. Akıl yürütme, kavramsallaştırma, tümdengelim ve tümevarım düşüncesinin çeşitli biçimlerini içerir. Akıl yürütmeyi içeren görevlerle ilgili sorunları olan çocuklar, kalıpları ve ilişkileri görmekte güçlük çekmekte, hatalı mantık kurmakta, tipik olarak sorgulamadan ve analiz etmeden, görünen en açık kavramı kabul etmekte ve bir matematik sürecinin arkasındaki “neden” i açıklayamamaktadırlar (Meyer, 2003).

Çocuklardaki akıl yürütme de tümdengelimli ve tümevarımlı akıl yürütme şeklindedir ve bu iki tip akıl yürütme, çocuklarda 2 yaşında başlamaktadır. Çocuk geliştikçe, tümdengelimli ve tümevarımlı akıl yürütme yetenekleri de gelişip, değişir. Ancak çocuk akıl yürütmekte zorlanıyorsa bunun başlıca sebebi deneyim eksikliğidir. Kavramsal gelişim artıkça artan akıl yürütme gücüne, öğretmenler ve ebeveynler katkıda bulunabilirler (Fathima ve Rao, 2008). Keenan'a (2006) göre de, çocukların akıl 
yürütme gelişim düzeyleri, eğitim ve deneyim ile değişebilmektedir. Akıl yürütme becerisinin en yoğun olarak kullanıldığ1 alanlardan biri olan matematiksel akıl yürütme, matematiğin temelini oluşturur. Bu sebeple matematik, bilişsel düzeyi belirli bir seviyede olan okul öncesi dönem çocuklarının akıl yürütme becerilerinin ortaya çıkarılmasında ve bu alanda ihtiyaç duydukları eğitimsel desteğin sağlanmasında önemli bir yere sahiptir (Ergül, 2014; Umay, 2003). Ayrıca Yeşildere ve Türnüklü (2007), matematiksel akıl yürütmenin, sayılar ve soyut matematiksel kavramların yanı sıra günlük hayatın içinde yer alan bir düşünme biçimi olduğunu vurgulamışlardır. Çocuklar, matematiksel akıl yürütme becerileri geliştikçe çevrelerindeki matematiksel düzeni fark etmeye başlarlar. Fark etme ve analiz yetenekleri de bu çerçevede giderek artar (National Research Council, 2009).

\section{İşitme Kayıplı Çocuklarda Matematik ve Akıl Yürütme Becerileri}

İşitme kayıplı çocuklar, işitsel yoksunluktan kaynaklı olarak, gelişimlerini takip eden süreçte, işiten yaşıtlarına göre farklılıklar göstermektedirler. Dil becerilerinin bilişsel gelişim ile iç içe olmasından dolayı işitme engelinin derecesi bilişsel gelişimi etkilemektedir. Buna bağlı olarak okuma- yazma, matematik becerilerinde güçlük yaşmakta ve bu durum akademik başarısızlık ile sonuçlanabilmektedir (MEB, 2014).

İşitme kayıplı öğrencilerin yaşadıklanı akademik güçlüklerin başında gelen matematik öğreniminde yaşadıkları zorlukların nedenleri olarak: Erken öğrenmeyi sağlayan deneyim yetersizlikleri, dile ilişkin yaşadıkları güçlükler, matematik dilinin doğası gereği soyut kavramlar içermesi, okuduğunu anlamada yaşanan zorluklar sayılabilmektedir. Matematikte okuma anlama oldukça önemlidir. Okuduğunu anlamada zorlanan öğrencilerin, matematikte diğer öğrencilere göre daha başarısız olmaları kaçınılmazdır. Nunes ve Moreno (2002) matematik öğretiminin genellikle karmaşık sözlü açıklamalar biçiminde olduğunu ve işitme kaybı nedeniyle karmaşık dilde güçlük yaşayan çocukların matematiksel kavramları ögrenmede de zorlandıklarını vurgulamaktadırlar. Tüm bunlara ek olarak matematik öğretmenlerinin ağılıklı dil odaklı çalışmaları, işitme kayıplı öğrencilerin matematiksel becerilerde daha fazla güçlük yaşamlarına neden olmaktadır.

Yapılan çalışmalarda, işitme kaybı olan çocuklarda matematiksel akıl yürütme ile ilgili farklı görüş belirten çalışmalar bulunmaktadır. Wood, Wood ve Howarth (1983) işitme kayıplı çocukların matematiksel akıl yürütme alanında normal işten çocuklarıdan farklı olduğunu belirtirken, Tanrıdiler (2013) işitme kayıplı çocukların matematiği yaşıtları gibi öğrendiğini ve sadece bu öğrenme sürecinin gecikmeli yaşanabileceğini belirtmişlerdir. Moores (2000) ise işitme kaybı olan 
öğrencilerin matematiksel kavramları öğrenirken karşılaştıkları büyük sorunlara rağmen, doğru eğitimsel müdahalelerle sorunların ortadan kaldırllabileceğini öne sürmektedir (akt. Sylvia, 2015).

Ulusal ve uluslararası literatür incelendiğinde koklear implantlı çocukların matematiksel akıl yürütme becerileri ile ilgili bir çalışmaya rastlanmamıştır. Bu doğrultuda bu çalışmada, anasınıfına devam eden okul öncesi dönemdeki (60-72 ay) ileri ve/veya çok ileri derecede işitme kaybına bağlı olarak koklear implant kullanan çocukların matematiksel akıl yürütme becerilerinin, normal işitmeye sahip çocuklarla karşılaştırılması amaçlanmıştır. Bu genel amaç doğrultusunda aşağı̆da yer alan sorulara cevap aranmıştır:

1-Koklear implant kullanan ve Nİ çocukların matematiksel akıl yürütme becerileri testinden aldıkları puanlar farklılık göstermekte midir?

2- Koklear implantlı ve Nİ çocukların, matematiksel akıl yürütme becerileri testinden aldıkları puanlar cinsiyete göre anlamlı farkl1lık göstermekte midir?

3- Koklear implantlı çocukların matematiksel akıl yürütme becerileri testinden aldıkları puanlar işitme kaybı tanı yaşı, koklar impljantasyon yaşı ve özel eğitime devam süresine göre anlamlı farklılık göstermekte midir?

4- Koklear implantlı ve Nİ çocukların, matematiksel akıl yürütme becerileri testinden aldıkları puanlar anne öğretim düzeyine göre anlamlı farkl1lı göstermekte midir?

5- Koklear implantlı çocukların yaşı, Kİ kullanım süresi, özel eğitime devam etme süresi ile matematiksel akıl yürütme becerileri testinden aldıkları puanlar arasında anlamlı ilişki var mıdır?

\section{YÖNTEM}

\section{Araştırma Modeli}

Bu çalışmada Kİ kullanan çocuklar ile normal işitmeye sahip yaşıtlarının matematiksel akıl yürütme becerileri arasında fark olup olmadığının belirlenmesi amacıyla nedensel- karşılaştırmalı betimsel araştırma yöntemi kullanılmıştır(Stevens, 2002).

\section{Araştırma Grubu}

Araştırmanın çalışma grubunu Ege Üniversitesi Tıp Fakültesi Hastanesi Kulak Burun Boğaz Anabilim Dalı'nda ileri ve/veya çok ileri derecede işitme kaybına bağlı olarak Kİ ameliyatı olmuş, 
anasınıfına ve özel eğitim merkezine devam eden KI’lı çocuklar ile işitme testi için başvuran ve işitme testi sonucuna göre işitmesi normal olan 5-6 yaş (60- 72 ay) aralığında, anasınıfı öğrencilerinden oluşturmaktadır.

Araştırmada yaşları 60-72 ay arasında değişen, 22 KI’lı (10 erkek ve 12 kız) ve yaş ve cinsiyete göre eşleştirilmiş 22 Nİ çocuk yer almaktadır. Koklear implantlı çocuklara ait demografik bilgiler Tablo 1 'de verilmiştir.

Tablo 1. KI’’ı Çocukların demografik özellikleri

\begin{tabular}{llllllll}
\hline \multicolumn{1}{c}{ Yaş(ay) } & N & $\%$ & Ort & SD & Min. & Maks. \\
\hline \multirow{2}{*}{ İşitme Kaybı Tanı Yaşı } & $3-6$ ay & 13 & 59,1 & 5,15 & 1,34 & 3 & 6 \\
Koklear İmplant Ameliyat Yaşı & $12-24$ ay & 12 & 54,5 & 16,92 & 4,29 & 12 & 24 \\
& 24 ay $<$ & 10 & 45,5 & 33,90 & 8,30 & 25 & 47 \\
Özel Eğitime Başlama Yaş1 & $5-12$ ay & 8 & 36,4 & 9,25 & 3,15 & 5 & 12 \\
& $13-24$ ay & 9 & 40,9 & 18,67 & 4,35 & 14 & 24 \\
\hline
\end{tabular}

Ort: Ortalama; SD: Standart sapma; Min: Minimum; Maks: Maksimum

Tablo 1 incelendiğinde, KI’lı çocukların 13’ü (\%59,1) 3-6 ay arasında, 9’u (\%40,9) 6 aydan sonra işitme kaybı tanısı almıştır. İşitme kaybı tanı yaşı, ortalama 10 aydır. Koklear implantlı çocukların en küçüğü 3 ay, en büyüğü 29 aylıkken tanılama yapılmıştır. Çocukların 12’sine (\%54,5) 12 -24 ay aralığında, 10’una (\%45,5) 24 aydan sonra implantasyon uygulanmıştır. En küçük 12 ay, en büyük 47 aylıkken koklear implant ameliyatı yapılmıştır ve ortalama Kİ ameliyatı yaşı yaklaşık 25 aydır. Koklear implantlı çocukların 8’i (\%36,4) 5-12 ay aralığında, 9’u (\%40,9) 13-24 ay aralığında, 5’i $(\% 22,7) 24$ aydan sonra özel eğitime başlamışlardır. Özel eğitime başlama yaşı ortalama 20 aydır. Özel eğitime devam etme süresi ortalama 46 aydır.

Araştırmaya katılan KI’lı çocukların annelerinin yaş ortalaması 33,23 44,77 (min: 22, maks: 43)

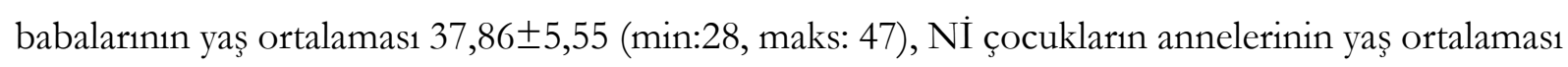

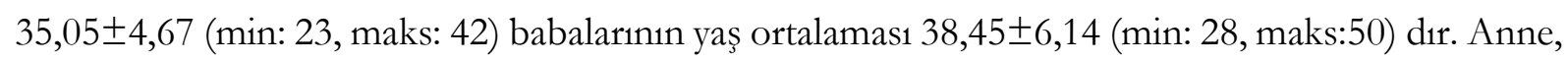
baba eğitim ve mesleklerine ilişkin demografik bilgiler Tablo 2'da verilmiştir.

Tablo 2. KI'lı ve Ni Çocukların anne ve babalarının demografik bilgileri

\begin{tabular}{|c|c|c|c|c|c|c|}
\hline & & \multicolumn{3}{|c|}{ Kİ } & \multicolumn{2}{|c|}{ Nİ } \\
\hline & & $\mathrm{n}$ & & $\%$ & $\mathrm{n}$ & $\%$ \\
\hline \multirow[t]{2}{*}{ Anne Öğretim } & İlköğretim & 11 & & 50,0 & 6 & 27,3 \\
\hline & Erken Çocukluk & & 2020 & $\begin{array}{l}\text { Journal } \\
\text { Volum }\end{array}$ & $\begin{array}{l}\text { hildh } \\
\cdot \text { Ma }\end{array}$ & \\
\hline
\end{tabular}




\begin{tabular}{llllll} 
& Lise ve üstü & 11 & 50,0 & 16 & 72,7 \\
Baba Ö̆ğretim & İlköğretim & 8 & 36,4 & 3 & 13,6 \\
\multirow{3}{*}{ Anne Meslek } & Lise ve üstü & 14 & 63,6 & 19 & 86,4 \\
& Çalışmıyor & 19 & 86,4 & 11 & 50 \\
Baba Meslek & Çalışıor & 3 & 13,6 & 11 & 50 \\
& Serbest Meslek & 11 & 50,0 & 3 & 13,6 \\
& İşçi & 4 & 18,2 & 5 & 22,7 \\
& Kamu Personeli & 5 & 22,7 & 6 & 27,3 \\
& Özel Sektör & 2 & 9,1 & 8 & 36,4 \\
\hline
\end{tabular}

Tablo 2'de KI'lı çocuların annelerinin eğitim düzeyleri incelendiğinde, annelerinin 11'inin (\%50) ilköğretim, 11'inin (\%50) lise ve üzeri düzeyde; Nİ grupta ise, 6'sının (\%27,3) ilköğretim, 16'sının $(\% 72,7)$ lise ve üzeri düzeydedir. Babaların eğitim düzeyleri incelendiğinde, KI’lı gruptaki çocukların babalarının 8’inin (\%36,4) ilköğretim 14’ünün $(\% 63,6)$ lise ve üzeri düzeyde; Nİ grupta ise, 3’ünün $(\% 13,6)$ ilköğretim, 19’unun $(\% 86,4)$ lise ve üzeri düzeyde eğitime sahip olduğu görülmektedir. Kİ’ı çocukların annelerinin 19’u $(\% 86,4)$ ev hanımıken, 3’ü $(\% 13,6)$ çalışmaktadır. Normal işiten çocukların annelerinin ise 11'i (\%50) ev hanımı, 11'i (\%50) çalışmaktadır. Koklear implantlı çocukların babalarının 11'i (\%50) serbest meslekle uğraşmaktayken, 4’ü $(\% 18,2)$ işçi, 5’i $(\% 22,7)$ kamu personeli olarak, 2'si $(\% 9,1)$ özel sektörde çalışmaktadır. Normal işiten çocukların babalarının 3’ü $(\% 13,6)$ serbest meslek, 5’i (\%22,7) işçi, 6’s1 (\%27,3) kamu personeli olarak, 8’i (\%36,4) özel sektörde çalışmaktadır.

Araştırmaya Ege Üniversitesi Tip Fakültesi Hastanesi Kulak Burun Boğaz Anabilim Dalı’nda ileri ve/veya çok ileri derecede sensörinöral işitme kaybına bağlı olarak Kİ ameliyatı olmuş ve en az 1 yıldır Kİ kullanan, 5-6 yaş (60-72 ay) arası, araştırmaya katılma kritelerini karşılayan ve aynı zamanda testi yapabilcek düzeyde dil gelişimine sahip Kİ kullanan çocuklar ile yaş( \pm 3ay) ve cinsiyete göre (Boons ve diğ., 2013; Le Normand, Ouellet ve Cohen 2008; Piştav Akmeşe ve Acarlar, 2016; Schorr, Roth ve Fox, 2008) eşleştirilmiş 22 normal işitmeye sahip çocuk dahil edilmiştir.

\section{Veri Toplama Araçları}

Koklear implantlı ve Nİ çocukların ebeveynlerine "Ebeveyn Onam Formu" formu imzalatıldıktan sonra, araştırmaya katılan çocuklar ve yetişkinlere ait genel bilgilerin yer aldığ " Olgu Rapor Formu” doldurulmuştur. Çocukların değerlendirme aşamasında KI’lı ve Nİ 5-6 yaş (60-72 ay) aralığındaki çocuklara yüz yüze görüşme yöntemiyle "Erken Matematiksel Akıl Yürütme Becerileri Değerlendirme Aracı" uygulanmıştır. 
Ebeveyn Onam Formu: Araştırmaya dahil edilen çocukların ebeveynleri bilgilendirilmiş ve araştırmayı kabul ettiklerine dair imzaları alınmıştır.

Olgu Rapor Formu: Çocuklara ve yetişkinlere ait genel bilgiler bu formda yer almaktadır. Bu form anne ve baba yaşı, mesleği ve öğretim bilgilerinin yanı sıra, çocuğun yaşı, Kİ ameliyatı olma yaşı, işitme kaybının tanılanma zamanı, özel eğitime başlama yaşı, özel eğitime devam etme süresi gibi sorulardan oluşmaktadır.

Erken Matematiksel Akıl Yürütme Becerileri Değerlendirme Aracı: Koklear implantlı ve Nİ çocukların matematiksel akıl yürütme becerilerini değerlendirmek için, Ergül (2014) tarafindan y1lında geliştirilen "Erken Matematiksel Akıl Yürütme Becerileri Değerlendirme Aracı" kullanılmıştır. Ölçekte ölçme ve verianalizi olasılık böümlerinde toplam 40 soru yer almaktadır. Ölçme bölümü altında yer alan toplamda 21 soruda 15 'i ölçme tümevarım 6’sı ölçme tümdengelimi oluştururken veri analizi olasılık altında yer alan 6 soru veri analizi olasılık tümevarım 13 soru veri analizi olasılık tümdengelimi oluşturmaktadır. Ölçekte uzunluk ve ağırlık kavramı ile ilgili 6 soru, alan ve hacim kavramı ile ilgili 6 soru, zaman sıralaması ile ilgili 3 soru, eldeki sonuçların doğruluğunu anlama (test etme) alanında 3 soru, sözel karşılaştırma problemlerinden 3 soru, şekil özelliklerini bilme alanında 3 soru, grafik oluşturma alanında 3 soru, resim inceleme ve resimdeki durumu tahmin ile ilgili 3 soru, grafik okuma ve sonuçlarını söyleme alanında 3 soru ve olasılık alanında 6 soru yer almaktadır. Soruların 28'i resimler, 9'u çeşitli materyaller ile ve geri kalan 3 soru da herhangi bir materyal kullanmaksızın yalnızca sözel olarak çocuklara yöneltilmektedir. Sorular 05 puan arasında puanlanmakta ve 200 puan üzerinden değerlendirilmektedir (Ergül, 2014).

\section{Verilerin Toplanmas1}

KI'lı ve Nİ çocukların ebeveynlerine ebeveyn onam formu imzalatıldıktan sonra, araştırmaya katılan çocuklar ve yetişkinlere ait genel bilgilerin yer aldığı olgu rapor formu doldurulmuştur. Daha sonra Erken Matematiksel Akıl Yürütme Becerileri Değerlendirme Aracı uygulanması çocukla bireysel görüşme şeklinde ve çocukların yaptıkları yorumları not almayı içeren şekilde gerçekleştirilmektedir. Uygulama süresi her çocuk için yaklaşık $25 \mathrm{dk}$ sürmüştür.

\section{Verilerin Analizi}

Kategorik değişkenler için sayı ve yüzde değerleri verilmiştir. Araştırmada yer alan sürekli değisskenlerin, normal dağglıma uygunluğunu test etmek için parametrik olmayan testlerden, Shapiro-Wilk testi kullanılmıştır. Normal dağılan sürekli değişkenler için ortalama, standart sapma, 
minimum ve maksimum değerlerinin yer aldığı tanımlayıc1 istatistikler hesaplanmış; normal dağılmayan sürekli değişkenler için ortanca değer ve çeyrekliklerarası genişlik değerleri (ÇAĞ) (interquartile range- IQR) kullanılmıştır. Gruplar arası karşılaştırmalar ve demografik bilgi formunda yer alan özelliklere ait grup karşılaştırmaları, veriler normal dağılım göstermediği için Mann Whitney U ve Kruskal Wallis H testleri ile yapılmıştır. Çalışmada yer alan sürekli değişkenler arasındaki ilişkiler için korelasyon katsayıları, Spearman's -Rho testi kullanılarak hesaplanmıştır. Araştırmadan elde edilen veriler SPSS 23.0 (Statistical Package for the Social Sciences) yazılımı kullanılarak analiz edilmiştir. p değerinin .05’in altında olduğu durumlar istatistiksel olarak anlamlı kabul edilmiştir.

\section{BULGULAR}

Matematiksel akıl yürütme becerileri testinde yer alan akıl yürütme alanlarından, ölçme alanına ait tümevarım ve tümdengelim olmak üzere iki çeşit akıl yürütme türü bulunmaktadır. Ölçmetümevarımda alanında, uzunluk, ağırlık, alan, hacim, zaman soruları; ölçme-tümdengelim alanında, eldeki sonuçların doğruluğunu test etme ve sözel karşılaştırma soruları yer almaktadır. Diğer akıl yürütme alanı, veri analizi/olasılık alanıdır. Veri analizi/olasılık-tümevarım alanında şekil özellikleri ve grafik oluşturma soruları; veri analizi/olasılık-tümdengelim alanında ise resim tahmin, grafik okuma ve olasılık soruları yer almaktadır. İzleyen bölümde araştırma sorularına göre araştırmanın bulgularına yer verilmektedir.

1-Koklear implant kullanan ve Nİ çocukların matematiksel akıl yürütme becerileri testinden aldıkları puanlar farklılık anlamlı göstermekte midir?

Koklear implantlı ve Nİ çocukların, MAYBA puanı ve alt test puanları açısından gruplar arasında fark olup olmadığı Mann-Whitney U testi ile incelenmiştir. Sonuçlar Tablo 3’te verilmiştir.

Tablo 3. KI'lı ve Nİ Çocukların matematiksel akıl yürütme becerileri puanları ve alt test puanlarına ilişkin Mann-Whitney U sonuçları

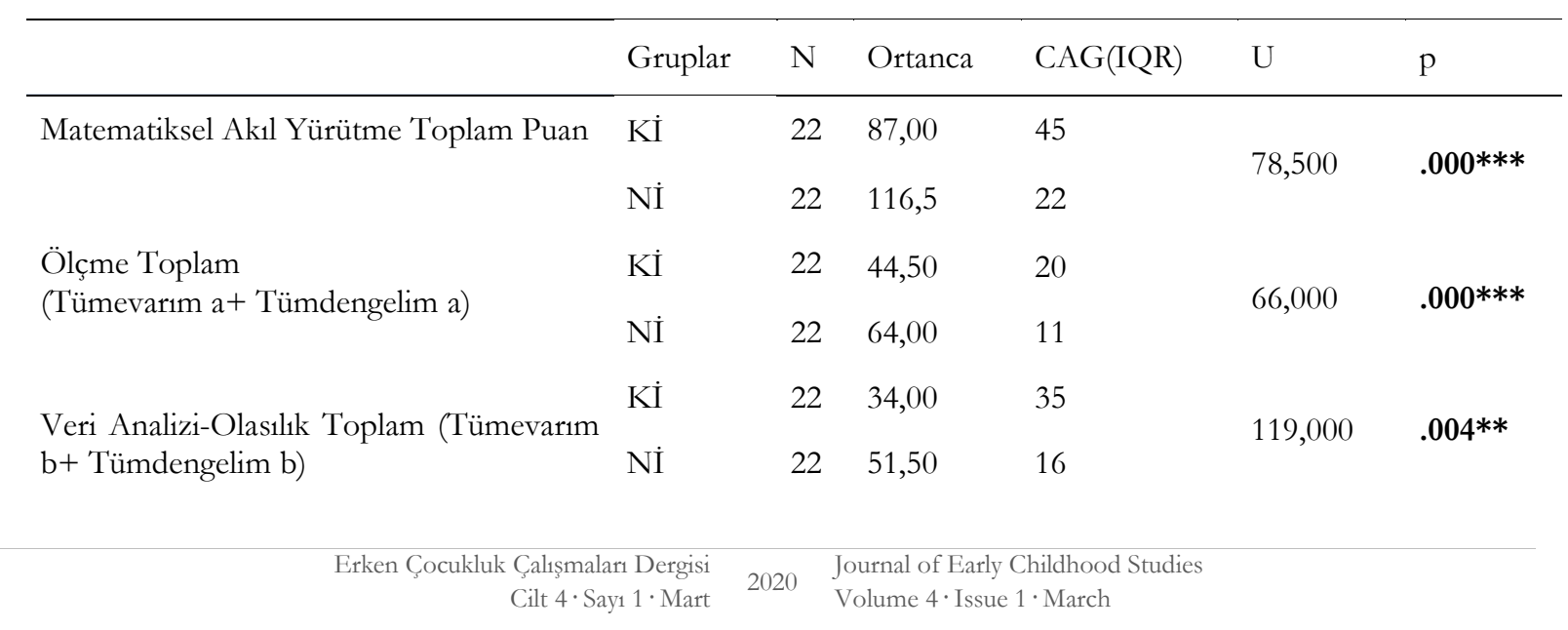




\begin{tabular}{|c|c|c|c|c|c|c|}
\hline \multirow{2}{*}{$\begin{array}{l}\text { Tümevarım Toplam } \\
\text { (Tümevarım a +Tümevarım b) }\end{array}$} & Kİ & 22 & 46,50 & 22 & \multirow{2}{*}{68,000} & \multirow{2}{*}{$.000 * * *$} \\
\hline & Nİ & 22 & 67,00 & 11 & & \\
\hline \multirow{2}{*}{$\begin{array}{l}\text { Tümdengelim Toplam } \\
\text { (Tümdengelim a +Tümdengelim b) }\end{array}$} & $\mathrm{KI}$ & 22 & 30,00 & 29 & \multirow{2}{*}{105,500} & \multirow{2}{*}{$.001 * *$} \\
\hline & NI & 22 & 46,00 & 15 & & \\
\hline
\end{tabular}
${ }^{*} \mathrm{p}<.05,{ }^{* *} \mathrm{p}<.01,{ }^{* * *} \mathrm{p}<.001$ a: Ölçme, b: Veri Analizi-Olasılık

Tablo 3’te, matematiksel akıl yürütme puanına ve alt test puanlarına ilişkin gruplar arası farklılığ1 belirlemek için yapılan Mann Whitney U testi sonuçlarına göre, iki grup arasında Matematiksel Akıl Yürütme Toplam (U=78,500, $\mathrm{p}=<.001)$, Ölçme Toplam $(\mathrm{U}=66,000, \mathrm{p}=<.001)$, Veri AnaliziOlasilik (U=119,000 p=.004), Tümevarım Toplam (U=68,000, $\mathrm{p}=<.001)$ ve Tümdengelim Toplam $(\mathrm{U}=105,500, \mathrm{p}=.001)$ alanlarında Nİ çocuklar lehine anlamlı bir fark bulunmuştur.

2- Koklear implantlı ve Ni çocukların, matematiksel akıl yürütme becerileri testinden aldıkları puanlar cinsiyete göre anlamlı farkl1l1k göstermekte midir?

Koklear implantlı çocukların matematiksel akıl yürütme becerileri puanının ve alt test puanlarının cinsiyete göre farklılaşıp farklılaşmadığı incelenmiş ve elde edilen bulgular Tablo 4'te verilmiştir.

Tablo 4 . KI’lı Çocukların matematiksel akıl yürütme becerileri puanlarının ve alt test puanlarının cinsiyete göre Mann-Whitney U sonuçları

\begin{tabular}{|c|c|c|c|c|c|c|}
\hline & Cinsiyet & $\mathrm{N}$ & Ortanca & CAG(IQR) & $\mathrm{U}$ & $\mathrm{p}$ \\
\hline \multirow{2}{*}{ Matematiksel Akıl Yürütme Toplam Puan } & $\mathrm{E}$ & 10 & 87,50 & 42 & \multirow{2}{*}{48,000} & \multirow{2}{*}{.429} \\
\hline & K & 12 & 78,00 & 58 & & \\
\hline \multirow{2}{*}{$\begin{array}{l}\text { Ölçme Toplam } \\
\text { (Tümevarım a + Tümdengelim a) }\end{array}$} & $\mathrm{E}$ & 10 & 49,00 & 19 & \multirow{2}{*}{43,000} & \multirow{2}{*}{.262} \\
\hline & K & 12 & 41,50 & 27 & & \\
\hline \multirow{2}{*}{$\begin{array}{l}\text { Veri Analizi-Olasılık Toplam } \\
\text { (Tümevarım b + Tümdengelim b) }\end{array}$} & $\mathrm{E}$ & 10 & 34,00 & 30 & \multirow{2}{*}{51,500} & \multirow{2}{*}{.575} \\
\hline & K & 12 & 35,00 & 37 & & \\
\hline Tümevarım Toplam & $\mathrm{E}$ & 10 & 56,00 & 20 & \multirow{2}{*}{46,500} & \multirow{2}{*}{.373} \\
\hline (Tümevarım a +Tümevarım b) & $\mathrm{K}$ & 12 & 43,50 & 36 & & \\
\hline \multirow{2}{*}{$\begin{array}{l}\text { Tümdengelim Toplam } \\
\text { (Tümdengelim a+Tümdengelim b) }\end{array}$} & $\mathrm{E}$ & 10 & 30,00 & 23 & \multirow{2}{*}{50,500} & \multirow{2}{*}{.531} \\
\hline & $\mathrm{K}$ & 12 & 29,50 & 35 & & \\
\hline
\end{tabular}

Tablo 4’te görüldüğü gibi, KI’lı erkek ve kız çocuklarının Matematiksel Akıl Yürütme Toplam Puan $(\mathrm{U}=48,000, \mathrm{p}>.05)$, Ölçme Toplam (U=43,000, p>.05), Veri Analizi-Olasıllik (U=51,500, p >.05), Tümevarım Toplam (U=46,500, p>.05), Tümdengelim Toplam (U=50,500, p>.05) alanlarından aldıkları puanlar arasında anlamlı bir farklılık bulunmamaktadır. Benzer şekilde Nİ grupta yer alan erkek ve kız çocukların Matematiksel Akıl Yürütme Toplam Puan (U=42,500, p>.05), Ölçme 
Toplam (U=50,500, p>.05), Veri Analizi-Olasilik Toplam (U=37,500, p>.05), Tümevarım Toplam $(\mathrm{U}=40,500, \mathrm{p}>.05)$, Tümdengelim Toplam $(\mathrm{U}=48,500, \mathrm{p}>.05)$ alanlarından aldıkları puanlar arasında cinsiyete göre istatistiksel olarak anlamlı bir farklılık elde edilememiştir.

3-KI’lı çocukların matematiksel akıl yürütme becerileri testinden aldıkları puanlar işitme kaybı tanı yaşı, koklear implantasyon yaşı ve özel eğitime başlama yaşına göre anlamlı farklılık göstermekte midir?

KI’lı çocuklar, işitme kaybının tanılandığı yaşa göre 2 gruba (6 ay öncesi ve 6 ay sonrası) ayrılarak karşılaştırılmıştır. İşitme kaybı tanı yaşına göre farklılaşıp farklılaşmadığı incelenmiştir. Sonuçlar Tablo 5’te verilmiştir.

Tablo 5. KI’’ı Çocukların matematiksel akıl yürütme becerileri puanının ve alt test puanlarının işitme kaybı tanı yaşına göre Mann-Whitney U sonuçları

\begin{tabular}{|c|c|c|c|c|c|c|}
\hline & Tanı Yaşı & $\mathrm{n}$ & Ortanca & CAG(IQR) & $\mathrm{U}$ & $\mathrm{p}$ \\
\hline \multirow{2}{*}{ Matematiksel Akıl Yürütme Toplam Puan } & 6 ay öncesi & 13 & 86,00 & 55 & \multirow{2}{*}{57,500} & \multirow{2}{*}{.947} \\
\hline & 6 ay sonras 1 & 9 & 88,00 & 55 & & \\
\hline \multirow{2}{*}{$\begin{array}{l}\text { Ölçme Toplam } \\
\text { (Tümevarım a + Tümdengelim a) }\end{array}$} & 6 ay öncesi & 13 & 47,00 & 24 & \multirow{2}{*}{42,500} & \multirow{2}{*}{.285} \\
\hline & 6 ay sonrasi & 9 & 43,00 & 19 & & \\
\hline \multirow{2}{*}{$\begin{array}{l}\text { Veri Analizi-Olasılık Toplam } \\
\text { (Tümevarım b + Tümdengelim b) }\end{array}$} & 6 ay öncesi & 13 & 33,00 & 32 & \multirow{2}{*}{56,500} & \multirow{2}{*}{.89} \\
\hline & 6 ay sonras1 & 9 & 41,00 & 40 & & \\
\hline Tümevarım Toplam & 6 ay öncesi & 13 & 47,00 & 24 & \multirow{2}{*}{54,000} & \multirow{2}{*}{.76} \\
\hline (Tümevarım a + Tümevarım b) & 6 ay sonrasi & 9 & 45,00 & 29 & & \\
\hline \multirow{2}{*}{$\begin{array}{l}\text { Tümdengelim Toplam } \\
\text { (Tümdengelim a+Tümdengelim b) }\end{array}$} & 6 ay öncesi & 13 & 29,00 & 32 & \multirow{2}{*}{51,500} & \multirow{2}{*}{.640} \\
\hline & 6 ay sonrasi & 9 & 33,00 & 31 & & \\
\hline
\end{tabular}

Tablo 5 incelendiğinde KI’lı çocuklarının Matematiksel Akıl Yürütme Toplam Puan (U=57,500, p >.05), Ölçme Toplam (U=42,500, p >.05), Veri Analizi-Olasılık Toplam (U=56,500, p >.05), Tümevarım Toplam $(\mathrm{U}=54,000, \mathrm{p}>.05)$, Tümdengelim Toplam $(\mathrm{U}=51,500, \mathrm{p}>.05)$ alanlarından aldıkları puanlar arasında işitme kaybı tanı yaşına göre istatistiksel olarak anlamlı bir farklılık bulunmamaktadır.

Koklear implantlı çocuklar, 2 yaş öncesi (12-24 ay) ve 2 yaş sonrası (24 ay<) ameliyat olma durumlarına göre gruplandırılarak karşılaştırılmıştır. Koklear implant ameliyatı olma yaşına göre test puanlarının farklılaşıp farklılaşmadığı incelenmiştir. Sonuçlar Tablo 6'da verilmiştir.

Tablo 6. KI’lı Çocukların matematiksel akıl yürütme becerileri puanının ve alt test puanlarının koklear implant ameliyatı yaşına göre Mann-Whitney U sonuçları

\begin{tabular}{|c|c|c|c|c|c|c|}
\hline & Kİ yaş1 & $\mathrm{n}$ & Ortanca & CAG(IQR) & $\mathrm{U}$ & $\mathrm{p}$ \\
\hline \multirow{2}{*}{ Matematiksel Akıl Yürütme Toplam Puan } & $12-24$ ay & 12 & 88,50 & 38 & \multirow{2}{*}{47,500} & \multirow{2}{*}{.410} \\
\hline & 24 ay $<$ & 10 & 67,50 & 58 & & \\
\hline \multirow{2}{*}{$\begin{array}{l}\text { Ölçme Toplam } \\
\text { (Tümevarım a + Tümdengelim a) }\end{array}$} & $12-24$ ay & 12 & 47,00 & 15 & \multirow{2}{*}{39,000} & \multirow{2}{*}{.166} \\
\hline & 24 ay $<$ & 10 & 36,50 & 26 & & \\
\hline
\end{tabular}




\begin{tabular}{|c|c|c|c|c|c|c|}
\hline \multirow{2}{*}{$\begin{array}{l}\text { Veri Analizi-Olasılık Toplam } \\
\text { (Tümevarım b + Tümdengelim b) }\end{array}$} & $12-24$ ay & 12 & 36,00 & 33 & \multirow{2}{*}{56,500} & \multirow{2}{*}{.792} \\
\hline & 24 ay $<$ & 10 & 32,00 & 38 & & \\
\hline Tümevarım Toplam & $12-24$ ay & 12 & 51,00 & 17 & \multirow{2}{*}{46,000} & \multirow{2}{*}{.356} \\
\hline (Tümevarım a + Tümevarım b) & 24 ay $<$ & 10 & 41,00 & 35 & & \\
\hline \multirow{2}{*}{$\begin{array}{l}\text { Tümdengelim Toplam } \\
\text { (Tümdengelim a+ Tümdengelim b) }\end{array}$} & $12-24$ ay & 12 & 33,00 & 30 & \multirow{2}{*}{51,000} & \multirow{2}{*}{.553} \\
\hline & 24 ay $<$ & 10 & 26,50 & 30 & & \\
\hline
\end{tabular}

Tablo 6 incelendiğinde iki grup arasında Matematiksel Akıl Yürütme Toplam Puan (U=47,500, p >.05), Ölçme Toplam (U=39,000, p >.05), Veri Analizi-Olasillk Toplam (U=56,000 p >.05), Tümevarım Toplam $(\mathrm{U}=46,000, \mathrm{p}>.05)$ ve Tümdengelim Toplam $(\mathrm{U}=51,000, \mathrm{p}>.05)$ alanlarında KI olma yaşına gore istatistiksel olarak anlamlı bir farklılık bulunmamıştır.

Koklear implantlı çocuklar, 5-12 ay, 13-24 ay ve 24 ay sonrası özel eğitime başlama yaşına (ay) göre gruplandırılarak karşılaştırılmışır. Koklear implantlı çocukların matematiksel akıl yürütme becerileri alt testinde hesaplanan puanlarının özel eğitime başlama yaşına göre farklılaşıp farklılaşmadığı incelenmiştir. Sonuçlar Tablo 7'de verilmiştir.

Tablo 7. Matematiksel akıl yürütme becerileri puanının ve alt test puanlarının özel eğitime başlama yaşına göre Kruskal-Wallis H sonuçları

\begin{tabular}{|c|c|c|c|c|c|}
\hline & $\begin{array}{l}\text { Özel Eğitime Başlama } \\
\text { Yaşı }\end{array}$ & $\mathrm{n}$ & Sira Ortalamas1 & $\mathrm{X}^{2}$ & $\mathrm{p}$ \\
\hline \multirow{3}{*}{$\begin{array}{l}\text { Matematiksel Akıl Yürütme } \\
\text { Toplam Puan }\end{array}$} & $5-12$ ay & 8 & 10,75 & \multirow{3}{*}{3,953} & \multirow{3}{*}{.139} \\
\hline & $13-24$ ay & 9 & 14,44 & & \\
\hline & 24 ay $<$ & 5 & 7,40 & & \\
\hline \multirow{3}{*}{$\begin{array}{l}\text { Ölçme Toplam } \\
\text { (Tümevarım a+ Tümdengelim a) }\end{array}$} & $5-12$ ay & 8 & 12,13 & \multirow{3}{*}{3,138} & \multirow{3}{*}{.208} \\
\hline & $13-24$ ay & 9 & 13,39 & & \\
\hline & 24 ay $<$ & 5 & 7,10 & & \\
\hline \multirow{3}{*}{$\begin{array}{l}\text { Veri Analizi-Olasılık Toplam } \\
\text { (Tümevarım b+ Tümdengelim b) }\end{array}$} & $5-12$ ay & 8 & 9,63 & \multirow{3}{*}{4,265} & \multirow{3}{*}{.119} \\
\hline & $13-24$ ay & 9 & 14,89 & & \\
\hline & 24 ay $<$ & 5 & 8,40 & & \\
\hline \multirow{3}{*}{$\begin{array}{l}\text { Tümevarım Toplam } \\
\text { (Tümevarım a + Tümevarım b) }\end{array}$} & $5-12$ ay & 8 & 11,31 & \multirow{3}{*}{3,125} & \multirow{3}{*}{.210} \\
\hline & $13-24$ ay & 9 & 13,89 & & \\
\hline & 24 ay $<$ & 5 & 7,50 & & \\
\hline \multirow{3}{*}{$\begin{array}{l}\text { Tümdengelim Toplam } \\
\text { (Tümdengelim a + Tümdengelim b) }\end{array}$} & $5-12$ ay & 8 & 10,44 & \multirow{3}{*}{4,257} & \multirow{3}{*}{.119} \\
\hline & $13-24$ ay & 9 & 14,67 & & \\
\hline & 24 ay $<$ & 5 & 7,50 & & \\
\hline
\end{tabular}

Tablo 7 incelendiğinde Ki'lı çocukların Matematiksel Akıl Yürütme Toplam, Ölçme Toplam, Veri Analizi- Olasılık Toplam, Tümevarım Toplam, Tümdengelim Toplam puanların özel eğitime başlama yaşına göre farklılaşmadığı saptanmıştır ( $\mathrm{p}>.05)$. 
4- Koklear implantlı ve Nİ çocukların, matematiksel akıl yürütme becerileri testinden aldıkları puanlar anne ve baba öğretim düzeyine göre anlamlı farkl1lık göstermekte midir?

Koklear implantlı ve Nİ çocukların değerlendirme aracından aldıkları puanların, anne öğretim düzeyine göre farklılaşıp farklılaşmadığı incelenmiştir. Sonuçlar Tablo 8’ de verilmiştir.

Tablo 8. KI’lı ve Nİ çocukların matematiksel akıl yürütme becerileri puanlarının ve alt test puanlarının anne ögretim düzeyine göre Mann-Whitney U sonuçları

\begin{tabular}{|c|c|c|c|c|c|c|}
\hline & Anne Öğrt. & $\mathrm{N}$ & Ortanca & CAG(IQR) & $\mathrm{U}$ & $\mathrm{p}$ \\
\hline \multirow{2}{*}{$\begin{array}{l}\text { Matematiksel Akıl Yürütme } \\
\text { Toplam Puan }\end{array}$} & İlköğretim & 11 & 53,00 & 39 & \multirow{2}{*}{13,000} & \multirow{2}{*}{$.002 * *$} \\
\hline & Lise ve üstü & 11 & 97,00 & 32 & & \\
\hline \multirow{2}{*}{$\begin{array}{l}\text { Ölçme Toplam } \\
\text { (Tümevarım a + Tümdengelim a) }\end{array}$} & İlköğretim & 11 & 34,00 & 25 & \multirow{2}{*}{14,000} & \multirow{2}{*}{$.002 * *$} \\
\hline & Lise ve üstü & 11 & 53,00 & 14 & & \\
\hline \multirow{2}{*}{$\begin{array}{l}\text { Veri Analizi-Olasılık Toplam } \\
\text { (Tümevarım b + Tümdengelim b) }\end{array}$} & İlköğretim & 11 & 21,00 & 22 & \multirow{2}{*}{17,000} & \multirow{2}{*}{$.004 * *$} \\
\hline & Lise ve üstü & 11 & 51,00 & 24 & & \\
\hline Tümevarım Toplam & İlköğretim & 11 & 40,00 & 23 & 4 & \\
\hline (Tümevarım a + Tümevarım b) & Lise ve üstü & 11 & 58,00 & 10 & & \\
\hline \multirow{2}{*}{$\begin{array}{l}\text { Tümdengelim Toplam } \\
\text { (Tümdengelim a+Tümdengelim b) }\end{array}$} & İlköğretim & 11 & 22,00 & 15 & \multirow{2}{*}{15,000} & \multirow{2}{*}{$.003 * *$} \\
\hline & Lise ve üstü & 11 & 43,00 & 22 & & \\
\hline
\end{tabular}

Tablo 8'e göre, Matematiksel Akıl Yürütme Toplam Puan (U=13,000, p=.002), Ölçme (U=14,000, $\mathrm{p}=.002)$, Veri Analizi-Olasilı $(\mathrm{U}=17,000, \mathrm{p}=.004)$, Tümevarım $(\mathrm{U}=14,000, \mathrm{p}=.002)$ ve Tümdengelim (U=15,000, $\mathrm{p}=.003)$ alanlarında anne öğretim düzeyinin, KI’lı çocukların puanlarında anlamlı bir farklılı̆ga yol açtığı görülmektedir. Eğitim düzeyi lise ve üstü olan annelerin çocuklarının aldıkları puanların ilköğretim düzeyinde eğitime sahip olan annelerin çocuklarının almış oldukları puanlardan daha yüksek olduğu belirlenmiştir. Baba eğitim düzeyine göre çocukların değerlendirme aracından aldıkları puanlar arasında anlamlı bir farklılık saptanmamıştır.

5- Koklear implantlı çocukların yaşı, Kİ kullanım süresi, özel eğitime devam etme süresi ile matematiksel akıl yürütme becerileri testinden aldıkları puanlar arasında analamlı ilişki var mıdır?

Koklear implantlı çocukların yaşı, Kİ kullanım süresi, özel eğitime devam etme süresi ile MAYBDA'ndan hesaplanan, ölçme tümevarım ve tümdengelim toplam puan ile veri analizi tümevarım ve tümdengelim toplam puan arasındaki ilişki spearman korelasyon katsayısı ile analiz edilmiştir. KI’lı çocukların, yaşı, Kİ kullanım süresi, özel eğitime devam etme süresi ile matematiksel akıl yürütme becerileri testinden aldıkları puanlar arasındaki ilişki Tablo 9'de verilmiştir. 
Tablo 9. KI’lı çocukların yaşı, Kİ kullanım süresi, özel eğitime devam etme süresi ile matematiksel akıl yürütme becerileri testinden aldıkları puanlar arasındaki ilişki

\begin{tabular}{llllll}
\hline & $\begin{array}{l}\text { MAYBA } \\
\text { Toplam }\end{array}$ & Tümevarım & Tümdengelim & Ölçme & $\begin{array}{l}\text { Veri Analizi } \\
\text { Olassllk }\end{array}$ \\
\hline Çocuğun Yaşı & $\mathbf{. 5 3 2}^{*}$ & $\mathbf{. 4 3 1}^{*}$ & $.593^{* *}$ & $\mathbf{. 4 4 0}^{*}$ & $\mathbf{. 5 5 0}^{* *}$ \\
Koklear İmplant Kullanım Süresi & $.427^{*}$ & $\mathbf{. 4 6 3}^{*}$ & .399 & $\mathbf{. 5 7 2 ^ { * * }}$ & .304 \\
Özel Eğitime Devam Etme Süresi & .394 & .349 & .372 & .420 & .276 \\
\hline
\end{tabular}

$* \overline{\mathrm{p}<.05, * * \mathrm{p}<.01, * * * \mathrm{p}<.001}$

Tablo 9 incelendiğinde Kİlı çocukların yaşları ile toplam puan, tümevarım toplam puan, ölçme toplam puan arasinda (sirasiyla $\mathrm{r}=.532, \mathrm{r}=.431, \mathrm{r}=.440$ ) orta düzeyde pozitif korelasyon bulunmaktadır. Yine KI’lı çocuğun yaşı ile tümdengelim ve veri analizi-olasılık toplam puanları arasında ( $\mathrm{r}=.593, \mathrm{r}=.550)$ yüksek düzeyde pozitif korelasyon mevcuttur. Koklear implantlı çocukların Kİ kullanım süresi ile toplam puan, tümevarım alt boyutları arasında (sırasıyla r=.427, $\mathrm{r}=.463$ ) orta düzeyde pozitif korelasyon bulunmaktadır. Yine KI’lı çocukların Kİ kullanım süresi ile ölçme toplam puan alt boyutları arasında $(\mathrm{r}=572)$ yüksek düzeyde pozitif korelasyon mevcuttur. Ayrıca çocuğun Kİ kullanım süresi ile tümdengelim toplam puan, veri analizi-olasılık toplam puan alt boyutlanı arasında istatistiksel olrak anlamlı bir ilişki olmadığı bulunmuştur. Koklear implantlı çocukların özel eğitime devam etme süresi ile toplam puanlar arasında bir ilişki olmadığ1 görülmüştür.

\section{SONUÇ ve TARTIŞMA}

İleri ve/veya çok ileri derecede işitme kaybına bağlı olarak koklear implant (Kİ) kullanan çocukların matematiksel akıl yürütme becerilerinin değerlendirilmesi ve bulgularının normal işiten (NI) yaşıtlarıyla karşılaştırılmasının amaçlandı̆̆ı bu çalışmanın sonucunda; değerlendirme aracının alt bileşenlerine ait (uzunluk, ağırlık, alan, hacim, zaman sıralaması, eldeki sonuçların doğrulunu test etme, sözel karşılaştırma, şekil özellikleri, grafik oluşturma, resimdeki durumu tahmin etme, grafik okuma, olasılık) alanlarındaki puanlar ve bu puanlar ile hesaplanan; tümevarım, tümdengelim, ölçme ve veri analizi-olasılık puanlarında Kİ kullanan çocukların işiten yaşıtlarının gerisinde kaldığı, aradaki farkın tüm alt alanlar için istatistiksel olarak anlamlı olduğu sonucuna ulaşılmıştır. Alan yazında, işitme kayıplı ve Nİ çocukların matematik performanslarının karşılaştırıldığı çalışmalarda farklı sonuçların olduğu görülmektedir. Bu çalışmanın sonuçlarını destekleyen şekilde, Edwards, Edwards ve Langdon (2013) KI'lı 23 çocuğun matematik performanslarını Nİ çocuklarla karşılaştırmış ve Kİlı grubun tüm testlerde Nİ grubun belirgin bir şekilde altında performans gösterdiğini; Leybaert ve Cutsem (2002) Nİ çocukların, işitme kayıplı katılımcılardan daha yüksek düzeyde performans sergilediklerini; Kritzer’in (2009) işitme kayıplı 4-6 yaş aralığındaki çocukların \%21,43'ünün 2-6 ay, \%25'inin 7-10 ay, \%39,9’unun 12-22 ay olacak şekilde Nİ yaşıtlarının gerisinde 
olduğunu belirtmişlerdir. Diğer bir çalışmada Kanda ve diğerleri (2012) 32 KI’lı çocuğun matematik performanslarını incelemişler ve KI’lı grubun \%70’inin, Nİ yaşıtlarının gerisinde kaldığını gözlemlemişlerdir. Mevcut çalışmamızdaki sonuçların aksine, Motasaddi-Zarandy, Rezai, Mahdavi-Arab ve Golestan (2009) 27 KI’lı çocuğun ilkokul matematik performansları Nİ sınıf arkadaşları ile karşılaştırılmış ve Kİlı çocukların yaklaşık \%59,3'ünün Nİ yaşıtlarına göre ortalamanın üzerinde başarı gösterdiğini tespit etmişlerdir. Diğer bir çalışmada Arfe ve diğerleri (2011) 4-5 yaş aralığındaki KI’lı çocukların sayısal karşılaştırma yeteneklerini analiz etmişler ve işitme engelli çocukların işiten yaşıtlarından daha iyi performans gösterdikleri belirtmişlerdir. Araştırmacılar elde ettikleri bulgular sonucunu temel alarak, işitme kayıplı çocukların yaşadıkları zorlukların içerisinde matematik alanının yer almadığı yorumunu getirmişlerdir. Ayrıca Khan, Edwards ve Langdon (2005) KI’lı çocukların sayısal becerilerinin, Nİ çocuklara benzer olduğunu; sözel becerilerinin ise Nİ yaşıtlarından geri olduğunu belirtmişlerdir. Gottardis, Nunes ve Lunt (2013) ise işitme kayıplı çocukların, Nİ yaşıtlarına kıyasla sözel matematikte gecikme gösterdiklerini, bu durumun dil becerileriyle güçlü bir şekilde ilişkili olduğunu ancak sayısal temsilde (sayma, toplama, çıkarma, çarpma, bölme) bu gecikmenin ortaya çıkmadığını vurgulamışlardır. Normal işiten ve işitme kayıplı çocukların matematiksel performanslarının farklı oluşu, işitme kayıplı çocukların matematiksel dili anlamada ve ifade etmede yaşadıkları zorluklara bağlanmakta ve bu sorun özellikle, sözel ifadelere dayalı problemlerde kendini göstermektedir (Kumaş ve Sümer, 2017). Yapılan çalışmalarda, KI'lı çocukların dilsel gecikmişlik ya da dil bozukluklarının, matematikte yaşadıkları zorlukların nedensel faktörü olarak açıklandığı görülmektedir (MotasaddiZarandy ve diğg., 2009). Yürütmüş olduğumuz çalışmada kullanılan "Matematiksel Akıl Yürütme Becerileri Değerlendirme Aracı”, sayısal temsilden ziyade sayısal akıl yürütmeye ait sözel temsil kabiliyetini değerlendirmektedir. Koklear implantlı çocukların yanlış cevap sayıları Nì çocuklara göre daha fazla olmakla birlikte, KI’’ı çocukların sorulan soruya ilişkin doğru cevabı buldukları halde, sonrasında cevaplarına ilişkin sözel olarak yöneltilen, "neden?" sorusuna cevap vermekte yani akıl yürütmekte güçlük yaşadıkları gözlenmiştir. Değerlendirme aracına ait puanlamada esas alınan nokta, sorunun doğru cevabından ziyade çocukların akıl yürütme biçimleridir. Çocuk yanlış cevap verip doğru biçimde akıl yürüttüğünde de puan almaktadır. Bu sebeple çocukların akıl yürütme biçimleri ve bu akıl yürütme biçimlerini aktarabilecekleri ifade edici dil becerileri önem kazanmaktadır. Akçamete (2003), Piştav Akmeşe ve Acarlar (2016) ve Yücel (2012), işitme kayıplı çocukların dil ve konuşma gelişimlerinin Nİ yaşıtları ile karşılaşıtııldığında sözcük dağarcıklarının sınırlı olduğunu, bu sebeple kısa ve basit cümlelerle iletişim sağladıklarını, Nİ çocuklarla işitme kayıplı çocukların sözcük dağarcıkları arasındaki bu farkın yaş ilerledikçe arttı̆̆ını ve bu çocukların kelimedeki ekleri kullanmada sorun yaşadıklarını, eş anlamlı ya da mecaz anlamlı kelimeleri ayırt 
etmekte, soru cümlelerini anlamakta ve bu sorulara yanıt vermekte, okumakta ve okuduğunu anlamada güçlükleri olduğunu belirtmişlerdir.

Araştırmamızda incelediğimiz bir diğer değişken olan cinsiyet faktörünün puanlardaki etkisi ele alındığında, KI’lı ve Nİ erkek ve kız çocuklarının MAYBDA'dan aldıkları puanları arasında anlamlı bir farklılık bulunmamıştır. Alanyazında da benzer şekilde matematik alanındaki yetkinlik açısından cinsiyetin bir farklılık yaratmadığı belirtilmektedir (Chang, Sandhofer ve Brown 2011; Güven ve Aydın, 2006). Taşkın (2013), okul öncesi dönem çocuklarının, yön-konum, miktar ve zamansıralama alanlarında cinsiyet faktörünün matematiksel beceriler üzerinde etkisinin olmadığını, benzer şekilde Wood, H. Wood ve Hawarth (1983), 414 işitme kayıplı ve 465 Nİ öğrencinin matematik başarılarını karşılaştırdığı çalışmalarında cinsiyetin matematik başarısı üzerinde anlamlı bir farklılık yaratmadığını ortaya koymuşlardır.

Koklear implant sonrası gelişimi etkileyen faktörler arasında işitme kaybı tanı yaşı çocukların implanttan sağladıkları faydada önemli bir etkendir (Gündüzder 2014; Piştav Akmeşe, 2015; Piştav Akmeşe ve Acarlar, 2016). Bu çalışmada işitme kayıplı çocuklar, işitme kaybı tanı yaşına göre 6 ay öncesi ve 6 ay sonrası olmak üzere iki gruba ayrılmış ve bu iki grubun matematiksel akıl yürütme becerileri arasında anlamlı bir farklılık bulunmamıştır. Alan yazında Yoshinaga-Itano, Sedey, Coulter ve Mehl (1998), 6 aydan önce ve 6 aydan sonra işitme kaybı tanısı alan çocukları değerlendirdikleri çalışmalarında, işitme kaybı tanısını 6 aydan önce almış çocukların dil gelişiminin, 6 aydan sonra işitme kaybı tanısı almış çocuklara göre, daha iyi sevide olduğunu ve erken tanı alan grubun Nİ yaşıtları ile benzer performans gösterdiklerini bulmuşlardır.

Araştırmamızda Kİ yaşının matematiksel akıl yürütme becerilerine olan etkisi incelendiğinde; 2 yaş öncesi (12-24 ay) ve 2 yaş sonrası (24 ay <) Kİ ameliyatı olan çocukların, Kİ yaşı ile MAYBDA'ndaki puanlar arasında anlamlı bir fark elde edilmemiş olsa da, gruplara ait ortanca değerlerde, Matematiksel akıl yürütme toplam puan, Ölçme toplam, Veri analizi-olasılık toplam, Tümevarım toplam, Tümdengelim toplam alanlarında 24 ay öncesinde Kİ ameliyatı olmuş çocukların puanlarının 24 ay sonrası Kİ ameliyatı olmuş çocuklardan daha yüksek olduğu bulunmuştur. Motasaddi-Zarandy, Rezai, Mahdavi-Arab ve Golestan (2009) yaptıkları çalısmada, Kİlı 27 çocuğu 2 yaş öncesi ve 2 yaş sonrası olmak üzere iki gruba ayırarak matematik performanslarını işiten yaşıtları ile karşılaştırdıkları çalışmanın sonucunda; Kİ ameliyatını 2 yaş öncesinde olan çocukların matematik performanslarının, 2 yaş sonrası implant olan çocuklardan belirgin olarak daha yüksek olduğunu belirtmişlerdir. Bir başka çalışmada, Kanda ve diğerleri (2012), KI’lı 32 çocuğu matematik testinden (Criterion-referenced testing (CRT) aldıkları puanlara göre iki 
gruba ayırmışlar ve yüksek puana sahip 14 çocuk ile düşük puana sahip 19 çocuğun tanımlayıcı özelliklerini karşılaştırmışlardır. Çalışmanın sonucuna göre, yüksek puana sahip çocukların koklear implant ameliyatını 3 yaş öncesinde olduğu, düşük puana sahip 19 çocukların ise 3 yaş sonrasında ameliyat olduğu tespit etmişlerdir. Araştırmacılara göre, işitme kayıplı çocuklar için Kİ kullanımı, Nİ yaşıtları ile arasında oluşan bu farkı azaltmaktadır.

İşitme kayıplı çocukların işitme kaybının tanısı ve işitme cihazı ya da Kİ sonrası en erken dönemden itibaren özel eğitim alması, implant başarısı için önemli bir diğer etkendir (Piştav Akmeşe, 2015). Çalışmamızda özel eğitime başlama yaşının matematiksel akıl yürütme becerilerine olan etkisini 512 ay, 13-24 ay ve 24 ay arası özel eğitime başlayan üç grup olarak karşılaştırıldığında ardaki farkın anlamlı olmadığı görülmüştür. İşitme kayıplı çocukların matematik performanslarını değerlendiren bir çalışmada, Traxler (2000), Stanford Başarı Testi ile 4808 işitme kayıplı öğrenciyi işiten yaşıtları ile karşılaştırmıştır. Çalışmanın sonucunda işitme kayıplı öğrencilerin performanslarının \% $\% 0$ oranla işiten yaşıtlarından daha düşük olduğunu belirtmiştir. Araştırmacı işitme kayıplı çocukların matematik başarısında; eğitim yaşı, eğitim ortamı ve eğitimin niteliğinin büyük önem taşıdığını ifade etmiştir. Gottardis ve diğerleri (2013) işitme kayıplı çocukların aldıkları eğitimin niteliğinin, onların yaşıtları ile aralarındaki matematiksel performans farkının önemli sebeplerinden biri olarak belirtmişlerdir. El-Hakim ve diğerleri (2001) ise KI’lı çocukların, özel eğitime devam etme süresine göre sözcük dağarcıklarını karşılaştırmışlar ve uzun süre eğitim alan çocukların sözcük dağarcıklarının, kısa süre eğitim alan çocukların sözcük dağarcıklarından daha iyi olduğunu belirtmişlerdir. Çalışmamızda yer alan sorulara ait karşılaştırmalı cevaplar açısından, KI’lı çocukların daha kısa ve basit cümleler kurduğu, ilişkisel karşılaştırma yerine kavramsal cevaplar verdikleri gözlenmiştir (-den büyük, -den küçük yerine büyük, küçük gibi). Diğer bir çalışmada Gündüzer (2014) erken tanının yanı sıra, özel eğitime başlama yaşının, ifade edici dil gelişimini etkilediğini belirtmiştir. MEB (2014), işitme kayıplı çocukların kelime hazinelerinin, Ni çocuklara kıyasla daha yavaş gelişmesi ve bu farkın yaş ilerledikçe açılması sebebiyle, işitme kayıplı çocukların gelişimi ve eğitim hayatlarının sorunsuz devamı için, özel eğitimin şart olduğu belirtilmektedir.

Çalışmamızda yer alan Kİlı çocukların farklı merkezlerde özel eğitime devam ettikleri gözönünde alındığında, aldıkları mevcut eğitimin niteliğinin çocukların matematiksel akıl yürütme performanslarına etki etmiş olabileceği düşünülebilir. Wood, Wood ve Howarth (1983), eğitimin, işitme kayıplı çocukların matematiksel başarıları üzerindeki etkisini incelemişler ve çocukların matematiksel performansları ile özel eğitim arasında çok düşük bir ilişki olduğunu bildirmişlerdir. Mevcut çalışmamızda yer alan "Bu pulların ortak özellikleri neler?” sorusunda, KI’lı çocukların ortak kelimesini bildikleri ve soruyu cevaplama yoluna gittikleri, Nİ çocukların büyük bir oranının 
ortak kelimesinin anlamını bilmedikleri için sorunun cevabını veremedikleri gözlemlenmiştir. Aradaki bu farkın, anasınıfının yanında özel eğitim merkezine de devam etmekte olan Kİlı çocukların aldıkları eğitimin içeriğinden kaynaklandığını düşünülmektedir. Çalışmamızdaki bulgular, genelleme yapmak zor olsa da hem özel eğitimin hem de anasınıfı eğitimin önemini ortaya koymaktadır. Bu nokta da Türkiyenin farklı bölgelerini de kapsayacak şekilde daha fazla sayıda Kİlı çocuk ile çalışıldığında genelleme yapılabilecek çok daha detaylı verilerin elde edilebileceği düşünülmektedir.

İsitme kayıplı çocukların eğitiminde anneler önemli bir rol üstlenmektedirler. Araştırmamızda çocukların matematiksel akıl yürütme becerileri ile anne öğretim düzeyinin ilişkisini incelediğimizde, matematiksel akıl yürütme toplam, ölçme, veri analizi-olasılık, tümevarım ve tümdengelim alanlarında lise ve üstü olan annelerin puanlarında anlamlı bir farklılığa yol açtığ görülmüştür. Normal işiten çocukların MAYBDA’ndan aldıkları puanlar, anne öğretim eğitim düzeyi açısından farklı1ık göstermemiştir. Yıldız (1999) çocukların okul başarısında ailenin rolünü araştırmış ve anne öğretim düzeyi yükseldikçe, çocuğun başarı seviyesinin de arttığını belirtmiştir. Benzer şekilde, Çanakçı ve Özdemir (2015) öğrencilerin matematik başarılarının, anne öğretim düzeyine göre anlamlı bir şekilde değiştiğini tespit etmişlerdir. Alan yazında birçok araştırmanın sonucu çalışmamızın sonucunu destekler şekilde anne öğretim düzeyi ile çocukların matematik performansı arasında pozitif yönlü doğrusal bir ilişki olduğu yöndedir (McMullen, 2005; Beaton, Mullis, Martin, Gonzalez, Kelly ve Smith 1996; Greenwood, 1997). Araştırma sonuçlarımıza göre, işitme kayıplı çocukların annelerinin, evde çocuklarıyla verimli vakit geçirdiklerini, görsel materyalleri (kitap, resim, oyuncak) etkin biçimde kullandıklarını ve bu materyallere ait durumları sözel olarak çocuğa aktarıyor olabileceklerini akla getirmektedir. Ayrıca oyun ve etkinliklerle, çocuklarına zaman ayırdıkları yorumu yapılabilir.

Araştırmamızda, çocuğun yaşı, Kİ kullanım süresi ve özel eğitime devam süresinin ile MAYBDA'na ait puanlar arasındaki ilişkiyi inceldiğimizde; KI’lı çocukların yaşları ile toplam puan, tümevarımn, ölçme tümdengelim ve veri analizi-olasılık toplam puanları arasında; Kİ kullanım süresi ile toplam puan, tümevarım ve ölçme toplam alt boyutları arasında pozitif yönlü korelasyon saptanmıştır. Elde ettiğimiz bulgulara benzer şekilde, Gottardis ve diğerleri (2013) işitme kayıplı çocukların matematik başarısında yaş faktörünün önemli olduğunu ifade etmişlerdir. Araştırmacılar, işitme kayıplı çocuklarla Nİ çocuklar arasındaki sayısal becerilere ait farkın, yaşla birlikte kapandığını fakat yaşın tek başına belirleyici olmadığını, bunun yanında eğitim içeriği ve Kİ kullanımının etkili olduğunu ifade etmişlerdir. 
Sonuç olarak, okul öncesi dönemdeki ileri ve/veya çok ileri derecede işitma kaybına bağlı Kİ kullanan çocukların belli düzeyde akıl yürütme becerisine sahip oldukları fakat işiten yaşıtlarıyla karşılaştırıldıklarında, Nİ çocukların gerisinde kaldıkları görülmüştür. Koklear implantlı çocukların Nİ çocuklara göre, genellikle MAYBDA'nda yer alan soruları cevaplarken elleriyle işaret ettikleri ve akabinde sorulan “neden?” sorusuna ya hiç cevap vermedikleri ya da kısa ve karşılaştırmadan uzak cevaplama yoluna gittikleri gözlemlenmiştir. Koklear implantlı çocuklar matematiğin temeli olan matematiksel akıl yürütme becerilerinde daha yüksek performans gösterebilmeleri için daha fazla desteğe ihtiyaç duymaktadırlar.

Çalışma daha fazla sayıda katılımcı ile gerçekleştirilerek, KI’lı çocukların matematiksel akıl yürütme becerisine etki edebilecek özellikleri daha ayrıntılı olarak tekrar değerlendirilebilir ve bu sayede elde edilen bulguların genellenebilirliği arttırılabilir. Orta derecede ve orta ileri derecede işitme kaybı olan çocuklar işitme cihazı kullanmaktadırlar. Araştırmanın bulguları göz önünde bulundurularak, benzer bir çalışma işitme cihazı kullanan ve Kİ kullanan işitme kayıplı çocuklarla yapılabilir. Araştırmanın tek merkezde yürütülmüş olması sınırlılı̆̆ıdır. Bu nedenle gelecek araştırmalar farklı merkezlerde daha geniş çaplı olarak yürütülerek genellenebilirliği arttırılabilir. Kİlı çocukların sorunun doğru yanıtını bildikleri halde, cevap vermekte zorlanma nedenlerinin kesin olarak belirlenebilmesi için ayrıntılı değerlendirmlerin yapılması gerekmektedir. Çalışmadan elde edilen bulgulara temel alınarak okulöncesi dönemde koklear implant kullanan çocukların eğitim programlarına dil becerilerine ek olarak matematiksel akıl yürütme becerilerinin dahil edilmesi çocukların akademik becerilerini artırarak daha başarılı olmalarını sağlayacaktır.

\section{KAYNAKÇA}

Akçamete, G. (2003). İşitme yetersizliği olan çocuklar. A. Ataman (Ed.). Özel Gereksinimli Cocuklar ve Özel Ë̆gitime Giriş (s.313-359). Ankara: Gündüz Yayıncilık.

Arfè, B., Lucangeli, D., Genovese, E., Monzani, D., Gubernale, M., Trevisi, P., \& Santarelli, R. (2011). Analogic and symbolic comparison of numerosity in preschool children with cochlear implants. Deafness and Education International, 13, 34-45.

Arnas, A., Y., Gül, D., E. \& Sı̆̆ırtmaç, A. (2003). 48- 86 ay çocuklar için sayı ve işlem kavramları testi'nin geçerlilik ve güvenirlik çalışması. Cukurova Üniversitesi Sosyal Bilimler Enstitüsü Dergisi, 12(12), 147-157.

Beaton A.E., Mullis I.V.S., Martin O.M., Gonzalez E.J., Kelly D.L., \& Smith T.A. (1996). Mathematics achievement in the middle school years. third international mathematics and science study(TIMSS). Boston College: Center for the study of testing, evaluation and educational policy. 
Boons T., Raeve L. D., Langereis, M., Peeraer, L.,Wouters, J., \& Wieringen, A. (2013). Expressive vocabulary, morphology, syntax and narrative skills in profoundly deaf children after early cochlear implantation. Research in Developental Disabilities, 34(6), 2008-2022.

Chang, A., Sandhofer, C. M., \& Brown, C. S. (2011). Gender biases in early number exposure to preschool-aged children. Journal of Language and Social Psychology, 30 (4), 440-450.

Çanakçı, O., \& Özdemir, A. Ş. (2015). Matematik başarısı ve anne-baba eğitim düzeyi. İstanbul Aydn Üniversitesi Dergisi, 7(25), 19-35.

Edwards, A., Edwards, L., \& Langdon, D. (2013). The mathematical abilities of children with cochlear implants. Child Neuropsychology, 19(2), 127-142.

El-Hakim, H., Levasseur, J., Papsin, BC., Panesar, J., Mount, RJ., \& Stevens, D. (2001). Assessment of vocabulary development in children after cochlear implantation. Archieves Otolaryngology Head Neck Surgery, 127(9),1053-9.

Erdoğan Çimen, S., \& Baran, G. (2003). Erken çocukluk döneminde matematik. Education and Science, 28(130), 32-40.

Ergül, A. (2014). Erken matematikesel akıl yürü̈tme becerileri değerlendirme arac geliştirilmesi. Yayımlanmamış Doktora Tezi, Hacettepe Üniversitesi Sağlık Bilimleri Enstitüsü. Çocuk Gelişimi ve Eğitimi Program1, Ankara.

Ergül, A. \& Artan, İ. (2015). Erken matematiksel akıl yürütme becerileri değerlendirme arac1 geliştirilmesi. Kuramsal Ë̆itimbilim Dergisi, 8(4), 454-485.

Fathima, S., \& Rao, D. B. (2008). Reasoning ability of adolescent students. India: Discovery Publishing House.

Greenwood, L. (1997). Psychological and contextual factors influencing mathematics achievement. Australian Association for Research in Education Annual Conference, Brisbane. Australia.

Gottardis, L., Nunes, T., \& Lunt, I. (2013). A synthesis of research on deaf and hearing children's mathematical achievement. Deafness and Education International, 13(3), 131-150.

Gündüzer, F. (2014). Koklear implant kullanan çocuklarda alici ve ïfade edï̈ dil gelisïminïn ïncelenmes̈̈. Yayımlanmamış Yüksek Lisans Tezi, Marmara üniversitesi Sağlık Bilimleri Enstitüsü, İstanbul.

Grünberg, D. (2013). (Ed.). Mantığın gelişimi (2. Basım). Ekişehir: Anadolu Üniversitesi Yayını No: 2424.

Güven, Y., \& Aydın, O. (2006). 5-6 yaş çocuklarmm akul yürütme yeteneği ile sezgisel düsünme yetenekleri arasındaki ilişki. I. Uluslararası Okul Öncesi Eğitim Kongresi Bildiri Kitabı. İstanbul: YAPA Yayınları.

Hughes, K. C., \& Galvin, K. L. (2013). Measuring listening effort expended by adolescents and young adults with a unilateral or bilateral cochlear implants or normal hearing. Cochlear Implants Int., 14, 121-129. 
Kanda, Y., Kumagami, H., Hara, M., Sainoo, Y., Sato, C., Yamamoto-Fukuda, T., \& Takahashi, H. (2012). What factors are associated with good performance in children with cochlear implants? from the outcome of various language development tests, research on sensory and communicative disorders project in japan: Nagasaki experience. Clinical and Experimental Otorbinolaryngology, 5(1), 59-64.

Keenan, T. (2006). An introduction to child development. UK: SAGE Publications.

Khan, S., Edwards, L., \& Langdon, D. (2005). The cognition and behavior of children with cochlear implants, children with hearing aids and their hearing peers: A comparison. Audiol Neurootol, 10(2), 117-126.

Köknel, Ö. (2003). Akıl ile düşünce gücü (2. Basım). İstanbul: Altın Kitaplar Yayınevi.

Kritzer, K.L. (2009). Barely started and already left behind: a descriptive analysis of mathematics ability demonstrated by young deaf children. Journal of Deaf Studies and Deaf Education, 14(4), 409-21.

Kumaş, Ö. A., \& Sümer, H. M. (2017). İşitme engelli olan ve olmayan öğrencilerin toplama ve çıkarmadaki işlem hataları. International Journal of Education, Science and Technology, 3(1), 1-12.

Le Normand, M.T., Ouellet, C., \& Cohen, H. (2003). Productivity of lexical categories in Frenchspeaking children with cochlear implants. Brain and Cognition, 53, 257-262.

Leybaert, J., \& Van Cutsem, M.N. (2002). Counting in sign language. Journal of Experimental Child Psychology, 81(4), 482-501.

Maltzan, H. (2005). Deaf students and problem solving in mathematics. Unpublished Master's Thesis, National Technical Institute for the Deaf Rochester institute of technology, New York.

McMullen, C. (2005). Student achievement in mathematics - the roles of attitudes, perceptions and family background. 01 Şubat 2019 tarihinde http://www.statcan.gc.ca/pub/81-004$\mathrm{X} / 2005001 / 7836$ eng.htm Web adresinden erişildi.

MEB. (2014). Çocuk gelişimi ve eğitimi: İsitme engelliler. Ankara: Milli Eğitim Bakanlı̆g.

Meyer, K. (2003). In class hard of hearing children face misunderstanding. 01 Şubat 2019 tarihinde https://www.academia.edu/774037/in_class adresinden erişildi.

Moores, D. F., Jatho, J. \& Creech, C. (2000). Issues and trends in instruction and deafness. American Annals of the Deaf, 146(2), 71-76.

Motasaddi-Zarandy, M., Rezai, M. H., Mahdavi-Arab, M., \& Golestan, B. (2009). The scholastic achievement of profoundly deaf children with cochlear implants compared to their normal peers. Arch Iran Med, 12(5), 441-447.

National Association for the Education of Young Children [NAEYC](2009). NAEYC standarts for early childhood professional preparation programs. 28 Temmuz 2015 tarihinde https://www.naeyc.org/files/naeyc/file/positions/ProfPrepStandards09.pdf adresinden erişildi. 
National Research Council. (2009). Mathematics Learning in Early Childhood: Paths Toward Exellence and Equity. Committee on Early Childhood. C.,T., Cross, T.,A., Woods, H., Schweingruber (Ed.). Center of education, division of behavioral and social science and education. USA: The National Academies Press.

Nunes, T., \& Moreno, C. (2002). An intervention program for promoting deaf pupils' achievement in mathematics. Journal of Deaf Studies and Deaf Education, 7, 120-133.

Piştav Akmeşe, P. (2015). Doğuştan ileri/çok ileri derecede işitme kayıplı çocukların dil becerilerine ilişkin araştırmaların incelenmesi. Ege Eğitim Dergisi, 16(2), 392- 407.

Piştav Akmeşe, P., \& Acarlar, F. (2016). Using narrative to investigate language skills of children who are deaf and with hard of hearing. Educational Research and Reviens, 11(15), 1367-1381.

Schorr, E.A., Roth, F.P., \& Fox, N.A. (2008). A comparison of the speech and language skills of children with cochlear implants and children with normalhearing. Communication Disorders Quarterly, 29(4), 195-210.

Sert Çıbık, A., \& Emrahoğlu, N. (2008). Proje Tabanlı Öğrenme Yaklaşımının Fen Bilgisi Dersinde Öğrencilerin Mantıksal Düşünme Becerilerinin Gelişimine Etkisi. Çukurova Üniversitesi Sosyal Bilimler Enstitüsü Dergisi, 17 (2), 51-66.

Stevens, J. P. (2002). Applied multivariate statistics for the social sciences, (Fourth Edition). Mahwah, New Jersey: Lawrence Erlbaum Associates, Inc.

Sylvia, M. (2015). Factors contrbuting to low achievement levels in mathematics among hearing impaired learners: a case of selected schools of Lusaka, Zambia. Unpublished Master's Thesis, The University of Zambia, Lusaka.

Şipal, R.F. (2008). Okul öncesi dönemde özel eğitim alan ve almayan ilkë̈gretim 4, 5 ve 6. simif işitme engelli cocuklarm zibin kuramı kapsamında yürütü̈ü işlevler açısından incelenmesi. Yayımlanmamış Doktora Tezi, Hacettepe Üniversitesi Sağlık Bilimleri Enstitüsü, Ankara.

Tanrıdiler, A. (2013). İşitme engelli öğrencilerle yapılan matematik öğretimi araştırmaları. Education Sciences, 8(1), 146-163.

Taşkın, N., \&Tuğrul, B. (2013). Okul öncesi dönemde matematik ile dil arasındaki ilişki üzerine bir inceleme. Yüzüncü Yal Üniversitesi Ë̆itim Fakültesi Dergisi, 11(1), 129-148.

Titus, J. C. (1995). The concept of fractional number among deaf and hard of hearing students. American Annals of the Deaf, 140(3), 255-262.

Traxler, C. (2000). Measuring up to performance standards in reading and mathematics: achievement of selected deaf and hard-of-hearing students in national norming of the 9th edition stanford achievement test. Journal of Deaf Studies Education, 5,337-48.

Umay, A. (2003). Matematiksel muhakeme yeteneği mathematical reasoning ability. Hacettepe Üniversitesi Ë̆itim Fakültesi Dergisi, 24, 234-243

Wilson, B. S., \& Dorman, M. F. (2008). Cochlear implants: a remarkable past and a brilliant future. Hearing Research, 242(1-2), 3-21 
Wilson, B.S. (2000). Cochlear implant technology. J.K Niparko(Ed.) Cocblear implants principles and practices. USA:Williams and Wilkins.

Wood, D.J., Wood, H.A., \& Howarth, S.P., (1983). Mathematical abilities of deaf school-leavers. British Journal of Developmental Psychology, 1, 67-73.

Yeşildere, S., \& Türnüklü, E. B. (2007). Examination of students' mathematical thinking and reasoning processes. Ankara University, Journal of Faculty of Educational Sciences, 40 (1), 181 213.

Yıldız, V. (1999). Okulüncesinde matematik eğitimi, işbirlikçi öğrenme ve geleneksel öğretimin okulöncesi çocuklarının temel matematik becerilerinin gelişimi üzerine etkisi. Ë̆̈tim ve Dilim Dergisi, 23 (2), 42 -50.

Yücel, E. (2012). İşitme engelli çocuklar. E.N. Metin (Ed.). Öz̧el Gereksinimli Cocuklar (s.109-141). Ankara: Maya Akademi Yayınevi.

Yoshinaga-Itano C., Sedey A., Coulter D., \& Mehl A. (1998). Language of Early- and LaterIdentified Children with Hearing Loss. Pediatrics. 102, 1161-71.

Zwolan, T. (2015). Audiology Information Series What is a cochlear implant? How does a cochlear implant work? 28 Ocak 2019 tarihinde http://www.asha.org/uploadedFiles/AIS-CochlearImplants.pdf adresinden erişildi. 